\title{
Development of a Contextual Based on E-learning (CBE) Model: The Effectiveness of Virtual Learning during the COVID-19 Pandemic for Health Policy Subjects
}

\author{
Reno Renaldi ${ }^{1 *}$,Jalius Jama ${ }^{2,}$ Wakhinuddin' ${ }^{3,}$ Muhammad Dedi Widodo ${ }^{4,}$ Leon Candra ${ }^{5}$ \\ ${ }^{1,4,5}$ Health Science Academy Hang Tuah,Pekanbaru-Riau, Indonesia. \\ ${ }^{2,3}$ Padang State University, Padang, Indonesia \\ *renorenaldi03@htp.ac.id
}

\begin{abstract}
The Covid-19 pandemic has brought about major changes in the learning process. This encourages us to develop a learning system during the pandemic. The Public Health Policy course is one of the conventional learning processes that are still memorized system so that it is deemed ineffective and needs a development model. The purpose of this research was to develop a Contextual Based Learning model (CBE) in the Health Policy course. This study used the Research and Development method (RnD). There are three stages of developing this CBE model, namely: design, development, and implementation. A total of 42 participants came from public health students who were divided into small groups (10 participants) and large groups (32 participants). Data analysis techniques consisted of validity and reliability tests, expert tests, practice tests, and model effectiveness tests. The forms of developing the CBE model are instrument assessment, model validation, module assessment, handbook student and handbook lecturer, and the development of an e-learning model. The results showed that the validity value of the development product was 0.7 (valid category). The practical test in the small group obtained an average value of 86.11 (very good practice category), while in the large group an average value of 84.97 (good practice category) was obtained. The effectiveness of developing the CBE model was sig<0.005. Conclusion. The development of the CBE model is considered effective in improving the learning process in health policy subjects.
\end{abstract}

Keywords

Contextual Based on E-learning (CBE), Virtual Learning, Health Policy Subject, Covid-19

\section{Introduction}

The suitability of the learning model is needed so that the learning objectives are achieved properly. The learning model is chosen based on the type of learning because this will affect learning outcomes. The lecturers' efforts in providing learning to students are an important aspect of achieving the success of learning objectives. Some important things that must be prepared include strategies planning, methods, techniques, and learning models [1].

The concept of $21^{\text {st }}$-century learning, namely: instruction should be student-centered, education should be collaborative, learning should have context, should be integrated with society. The four learning principles will be one of the foundations in the learning process. However, the fact is that to carry out the learning process these four principles have not been fully implemented and used as a pillar of learning, especially in higher education [2]. Improved systems and learning processes, especially when entering the world of work because they are required to be able to analyze a problem in health and be able to make decisions for policies. To improve this learning process, it is necessary to adapt to $21^{\text {st- }}$ century learning principles. One of the learning models that can be developed is the contextual learning model or Contextual Base on E-Learning (CBE) [3]. This concept is an active learning model in which students not only receive information but are also able to manage the information by connecting the context of life so that students get new knowledge [4]. The Public Health Policy course is one of the conventional learning processes that are still memorized system so that it is deemed ineffective and needs a development model. This study aims to describe the effectiveness of developing a CBE learning model in a health policy subject.

\section{Literature Review}

Contextual teaching and learning (CTL) or the concept of relating subject matter to meaningful situations that are relevant to students lives, offer one promising approach to helping students learn more effectively [5]. According to Satriani et al [6] states that CTL motivates the learners to take charge of their own learning ang to relate between knowledge and its application to the various contexts of their lives. While Bern and Erickson [7] said that contextual learning has characteristics are follows interdisciplinary learning, problem-based learning and external context for learning.

While, Surdin [8] states that the characteristics of contextual learning known as REACT, are follows: Relating, learning in the life experience context. Applying, learning when knowledge was introduced in the using context. Cooperating, learning through interpersonal communication and mutual sharing context. Transferring, using knowledge learning in the context or new situation.

Learning model of contextual based on e-learning bases to constructivism philosophy which assumes that knowledge is the result of human construction. Humans construct their knowledge through their interactions with objects, phenomena, experiences and their environment. A 
knowledge is considered true if that knowledge can be useful for dealing with and solving problems or phenomena accordingly [9]. According to Bern and Erickson [7], it can be implemented through five approaches, are follows: (1) Problem Based Learning, (2) Cooperative Learning, (3) Project Based Learning, (4) Service Learning, (5) Work Based Learning.

The learning strategy that will be applied in this research is contextual learning based on e-learning in health policy analysis. Contextual learning is a conception of learning that helps lecturers to relate course material to real life and motivates students to make connections between the knowledge they learn and their lives. It is hoped that through contextual learning the concepts of study can be integrated in the real-life context in the hope that students can understand what they are learning better and easier. In contextual learning, the lecturer links the context within the learning framework in order to increase the meaning of student learning,

\section{Methods}

This study was used by the Research and Development method $(\mathrm{RnD})$. There are three stages of developing this Contextual Based on E-learning model, namely: design, the model of development, and implementation. Types of qualitative descriptive data and reflective data. Descriptive data in the form of comments, criticisms, suggestions, corrections, and assessments given by experts. Reflective data in the form of comments and interpretations by researchers. Quantitative data in the form of pre-test and post-test scores were obtained from the implementation of the effectiveness test of this model. A total of 42 participants came from public health students. Divided into small groups (10 participants) and large groups (32 participants). The assessment instrument used a questionnaire and interviews. Data analysis techniques consisted of validity and reliability tests, expert tests, practice tests, and model effectiveness tests used the t-test statistically

\section{Results}

\section{Design}

This design starts from setting goals, designing or teaching and learning activities, designing learning devices, designing learning materials. The design of this learning method is still conceptual and will underlie the subsequent development process. The steps taken are: arranging learning objectives, Compiling tests based on learning objectives, Compiling e-learning models of CBE. The initial design of contextual e-learning consisted of several menus consisting of the home menu, curriculum, perception, subject matter, discussion, reflection, and assignments.

The integration of e-learning with the CBE model can help students build virtual learning environments without reducing the components of the contextual learning model. Students can also build constructivist thinking and inquiry thinking virtually. Educators can provide case studies, in the form of materials, modules, videos, and others. The use of this application starts from login, registration at https://E-
Learning-stikescbe.com. On the registration page, users can fill in their data, student ID numbers, full name, semester selection, email, and password. Then hit the register button. Then just waiting for confirmation from the admin or lecturer to be able to use the application.

\section{Model of Development}

This development stage is to realize a design that has been designed and validates or assesses the feasibility of the model design. This validation was carried out in 2 stages, namely product validation and practical testing. Product validation can be carried out with the help of several experts who are experienced in their fields, and experts in the field of learning media. Therefore, researchers present several expert lecturers who are competent in the fields used to assess this product. The form of development carried out is application design and learning modules. Following are the criteria for all the model instruments Contextual Based on E-learning (Table 1).

Tabel 1. Instrument Validation Criteria for a Contextual Based on E-learning Model

\begin{tabular}{|l|l|l|l|l|l|}
\hline $\begin{array}{l}\text { Validation } \\
\text { Criteria }\end{array}$ & $\begin{array}{c}|c| \\
1^{\text {st }} \\
\text { Validator }\end{array}$ & $\begin{array}{c}2^{\text {nd }} \\
\text { Validator }\end{array}$ & $\begin{array}{c}3^{\text {rd }} \\
\text { Validator }\end{array}$ & Average & Category \\
\hline $\begin{array}{l}\text { Instrument } \\
\text { value }\end{array}$ & 0,696 & 0,734 & 0,747 & 0,726 & Valid \\
\hline $\begin{array}{l}\text { Model } \\
\text { Validation }\end{array}$ & 0,740 & 0,716 & 0,735 & 0,730 & Valid \\
\hline $\begin{array}{l}\text { Assessment } \\
\text { Module }\end{array}$ & 0,706 & 0,727 & 0,701 & 0,711 & Valid \\
\hline $\begin{array}{l}\text { Learning } \\
\text { Media }\end{array}$ & 0,706 & 0,703 & 0,714 & 0,708 & Valid \\
\hline $\begin{array}{l}\text { Lecturer } \\
\text { Handbook }\end{array}$ & 0,743 & 0,706 & 0,716 & 0,722 & Valid \\
\hline $\begin{array}{l}\text { Student } \\
\text { Handbook }\end{array}$ & 0,716 & 0,716 & 0,706 & 0,713 & Valid \\
\hline $\begin{array}{l}\text { E-learning } \\
\text { model }\end{array}$ & 0,701 & 0,713 & 0,713 & 0,709 & Valid \\
\hline
\end{tabular}

Table 1 reveals that the evaluation of each validator on the average validation criteria was $>0.7$. For the validation value $\geq 0.6$, this can be interpreted as a fairly high coefficient. So that it can be categorized as "valid". This means that the CBE model is considered suitable for use in learning applications.

Practicality test carried out in small groups and large groups. A small group consists of 10 students and a large group of 30 students. They are required to operate elearning. After that asked to fill out a questionnaire. The results of this practicality test consist of attractiveness, development, ease of use, model function, and reliability. Based on the lecturers' assessment, an average percentage of $76 \%$ was obtained in the practical category. From this average value, it can be proven that the lecturers are very supportive of the application of this model. The practical test in a small group of students (10 participants) obtained an average score of 86.11 (very good practice category). While the practical test on a large group of students (32 participants) obtained an average value of 84.97 (good practice category). 


\section{Implementation}

The implementation stage is the phase of introducing the learning model. Having gone through Phase I validation then revisions are made to produce a model that is ready to be implemented. The implementation of the e-learning model development is carried out in two stages of field testing. The implementation stage is carried out to see the effectiveness of model development. Stage II, after the revised stage I model, then the model was tried again on 42 students (a small group of 10 participants, a large group of 32 participants). In the procedure, students are given elearning development media. During the learning process using e-learning, researchers observed the effectiveness of students in using e-learning based on affective and psychomotor aspects through observation sheets. The assessment process consists of a pre-test and post-test (Table 2)

Table 2. The implementation value of the Contextual Based on E-learning Model (Control Group)

\begin{tabular}{|l|r|r|r|r|}
\hline \multicolumn{3}{|c|}{ Small-Group (Control Group) } & \multicolumn{2}{c|}{$\begin{array}{c}\text { Large Group (Control } \\
\text { Group) }\end{array}$} \\
\hline & Pretest & \multicolumn{1}{|c|}{ Post-test } & \multicolumn{1}{c|}{ Pretest } & \multicolumn{1}{c|}{ Post-test } \\
\hline N: Valid & 10 & 10 & 30 & 30 \\
\hline \multicolumn{1}{|c|}{ Missing } & 0 & 0 & 2 & 2 \\
\hline Mean & 62,60 & 72,40 & 65,33 & 70,33 \\
\hline Median & 67,00 & 71,00 & 67,00 & 70,00 \\
\hline Mode & $67 \mathrm{a}$ & $68 \mathrm{a}$ & 67 & 70 \\
\hline Std. Deviation & 12,313 & 6,096 & 11,604 & 5,634 \\
\hline Variance & 151,600 & 37,156 & 134,644 & 31,747 \\
\hline Range & 40 & 16 & 47 & 20 \\
\hline Minimum & 33 & 64 & 33 & 60 \\
\hline Maximum & 73 & 80 & 80 & 80 \\
\hline Sum & 626 & 724 & 1960 & 2110 \\
\hline
\end{tabular}

Table 3. The implementation value of the Contextual Based on E-learning Model (Experiment Group)

\begin{tabular}{|l|r|r|r|r|}
\hline \multicolumn{2}{|c|}{ Small-Group (Experiment Group) } & \multicolumn{2}{c|}{$\begin{array}{c}\text { Large Group } \\
\text { Experiment Group) }\end{array}$} \\
\hline & Pretest & \multicolumn{1}{c|}{ Post-test } & Pretest & Post-test \\
\hline N: Valid & 10 & 10 & 32 & 32 \\
\hline \multicolumn{1}{|c|}{ Missing } & 0 & 0 & 0 & 0 \\
\hline Mean & 66,70 & 82,00 & 66,03 & 85,69 \\
\hline Median & 67,00 & 82,00 & 67,00 & 86,00 \\
\hline Mode & $67 \mathrm{a}$ & 78 & 73 & 78 \\
\hline Std. Deviation & 11,314 & 6,532 & 13,771 & 7,023 \\
\hline Variance & 128,011 & 42,667 & 189,644 & 49,319 \\
\hline Range & 40 & 22 & 67 & 20 \\
\hline Minimum & 47 & 70 & 20 & 76 \\
\hline Maximum & 87 & 92 & 87 & 96 \\
\hline Sum & 667 & 820 & 2113 & 2742 \\
\hline
\end{tabular}

Table 2 shows that in the control group there was an increase in post-test scores in both groups. For the small group, mean scores ranged from 62.60 to 72.40 . While for large groups the average value is 65.33 to 70.33 . Table 3 reveals that in the experimental group there was an increase in post-test scores in both groups. For the small group, the average score was 66.70 to 82.00 . Meanwhile, for large groups, the average value is 66.03 to 85.69 . It appears that the increase in the effectiveness value in the experimental group is greater than the control group.

\section{Table 4. The Effectiveness of Development Contextual Based on E-learning Model (t-test for the experiment and the control group)}

\begin{tabular}{|l|c|c|c|c|c|c|}
\hline \multicolumn{1}{|c|}{ Value } & \multicolumn{5}{|c|}{$\begin{array}{c}\text { the t-test (Small } \\
\text { Group) }\end{array}$} & \multicolumn{2}{c|}{ the t-test (Large Group) } \\
\hline & $\mathrm{t}$ & $\mathrm{df}$ & $\begin{array}{l}\text { Sig (2- } \\
\text { tailed) }\end{array}$ & $\mathrm{t}$ & $\mathrm{df}$ & $\begin{array}{r}\text { Sig (2- } \\
\text { tailed) }\end{array}$ \\
\hline $\begin{array}{l}\text { Equal } \\
\text { variances } \\
\text { assumed }\end{array}$ & 398 & 18 &, 003 & 9,456 & 60 &, 000 \\
\hline $\begin{array}{l}\text { Equal } \\
\text { variances not } \\
\text { assumed }\end{array}$ & 398 & 17,915 &, 003 & 9,523 & 58,636 &, 000 \\
\hline
\end{tabular}

Note: sig=significant set was $p$-value $<0,005$

Table 4 reveals that the development of the CBE model is considered effective with sig $<0.005$. It proves that the development of the CBE model is feasible to be implemented in public health students.

\section{Discussions}

Learning activities provide motivation or attract attention, explain learning objectives to students, and remind elearning prerequisites. The learning system must provide a stimulus to topics and concepts. Provides study instructions, provides feedback, assesses performance, and concludes. All of these aspects are used in the implementation of practical learning strategies developed in the development of learning models [10]. In planning a good lesson must be able to involve activities to allocate time use, choose appropriate learning methods, create student interest, and build a productive learning environment. Even careful planning is required for many aspects of modern life. However, lesson planning can also have undesirable consequences, causing lecturers to be insensitive to student needs and ideas [11].

The learning model is a description of the learning environment, including our behavior as teachers when the learning model is used. Learning models have various functions, namely as lesson planning and curriculum for designing materials including multimedia [12]. This elearning-based contextual learning model implements a holistic learning process and aims to help students understand the meaning of learning material by linking the learning material to the context of students' daily lives so that students can have flexible and dynamic knowledge or skills so that they can actively construct their understanding. This learning model can make students active and creative in the learning process because students build their knowledge through active involvement in the classroom during the learning process [13].

E-learning refers to the use of internet technology to deliver a series of solutions that can enhance knowledge and skills [14]. The difference between traditional learning and e-learning is that a lecturer is considered a knowledgeable person and must deliver on his knowledge. Meanwhile, in elearning, the main focus is Student Center Learning (SCL). 
Students are independent at certain times and are responsible for their learning. The e-learning atmosphere will encourage students to play a more active role in their learning. Students make designs and search materials with their efforts and initiatives [5].

Contextual Based E-learning as a user of information and communication technology networks in the teaching and learning process. Another term that refers to the same thing is online learning or web-based learning [15]. Through elearning, it allows the teaching and learning process through computers in its place without having to physically sit in the class [16].

\section{Conclusion}

The development of a Contextual Based on E-learning (CBE) Model is considered effective in improving virtual learning during the COVID-19 pandemic in Health Policy subjects. CBE model as a solution and control management in the learning process for online learning. The results of this study can be used as a guide for the development of learning methods although it is necessary to do a comparison test with other campuses with various curricula. This is a challenge for Indonesia to be able to realize quality education, producing graduates who have skills in various fields.

\section{Acknowledgement}

We thank all who participated in this research. We appreciate all public health students, staff, and lecturers of STIKes Hang Tuah Pekanbaru, Riau Province for their cooperation in facilitating our research.

\section{References}

[1] C. Jones, C. Reichard, and K. Mokhtari. Are students' learning styles discipline-specific? Community College Journal of Research and Practice, vol. 27, no. 5, pp. 363-375, (2003).

[2] Nichols, J. "Four Essential Rules $21^{\text {st }}$ Century Learning." [Online]. (2013) http://www.teachthought.com/learning/4-essentialrules-of-21st-century-learning/

[3] Bettye P. Smith. Contextual Teaching And Learning Practices In The Family and Consumer Sciences Curriculum, (2010)

[4] Clemente Charles Hudson, Vesta R. Whisler. Contextual Teaching and Learning for Practitioners. Adult and Career Education, Valdosta State University Valdosta, GA 31602, USA, (2011).

[5] Spooner, Rivera, Browder, Baker, Salas. Teaching Emergent Literacy Skills Using Cultural Contextual Story - Based Lessons. Research and Practice for Persons with Severe Disabilities. Vol 34, No. 3- 4. Page 102 - 112, (2009).

[6] Satriani, Intan, et al. Contextual Teaching and Learning Approach to Teaching Writing. Indonesian Journal of Applied Linguistics, Vol. 2, No. 1, pp. 10-
22, (2012).

[7] Bern, Robert G. And Erickson, Patricia M. Contextual Teaching and Learning: Preparing Student for the New Economy. The Highlight Zone. (2001).

[8] Surdin. The Effect of Contextual Teaching and Learning (CTL) Models on Learning Outcomes of Social Sciences of The Material of Forms The Face of The Earth on Class VII of Junior High School. International Journal of Education and Research (ISSN: 2411-5681), 6(3), 57-64, (2018).

[9] Johnson E.B. Contextual Teaching \& Learning, What it is and why it's here to stay. California: Corwin Press, Inc, (2002).

[10] Dick, Walter, Carey, Lou \& Carey, James O. The Systematic Design of Instruction. Boston: Pearson, (2005)

[11] Arends, Richard J. Learning to Teach, Boston, New York, McGraw-Hill Companies, Inc, (2004)

[12] Bruce Joyce, Marsha Weil, dan Emily Calhoun, Models of Teaching Yogyakarta: Pustaka Pelajar, (2011)

[13] Borg, W.R. dan Gall, M.D. Educational Research: An Introduction, $5^{\text {th }}$ Edition. New York: Longman. (1989)

[14] Keegan Desmond et.al, An Introduction To Mobile Learning, (2008)

[15] Caroline, Howard., Schenk, K. and Discenza, R. Distance Learning and University Effectiveness: Changing Educational Paradigms for Online Learning. Hershey. London, Melbourne, Singapore: Information Science Publishing, (2004)

[16] Surdin. The Effect of Contextual Teaching and Learning (CTL) Models on Learning Outcomes of Social Sciences of The Material of Forms The Face of The Earth on Class VII of Junior High School. International Journal of Education and Research (ISSN: 2411-5681), 6(3), (2018), pp 57-64. 